\title{
Efektivitas Probiotik Lactobacillus plantarum 2C12 dan Lactobacillus acidophilus 2B4 Sebagai Pencegah Diare pada Tikus Percobaan
}

\author{
The Effectivities of Probiotic Lactobacillus plantarum 2C12 and \\ Lactobacillus acidophilus 2B4 as Antidiarrhea on Rats
}

\author{
I. I. Ariefa, B. Sri Laksmi Jenie ${ }^{\text {b }}$, M. Astawan ${ }^{\text {b }}$, \& A. B. Witarto ${ }^{\text {c }}$ \\ aDepartemen Ilmu Produksi dan Teknologi Peternakan, Fakultas Peternakan, Institut Pertanian Bogor \\ Jln. Agatis, Kampus IPB Darmaga, Bogor 16680 \\ ${ }^{b}$ Departemen Ilmu dan Teknologi Pangan, Fakultas Teknologi Pertanian, Institut Pertanian Bogor \\ 'Pusat Penelitian Bioteknologi, Lembaga Ilmu Pengetahuan Indonesia \\ Jln. Raya Bogor Km. 46 Cibinong 16911 \\ (Diterima 05-05-2010; disetujui 03-09-2010)
}

\begin{abstract}
The aim of this study was to evaluate the effectiveness of probiotics Lactobacillus plantarum $2 \mathrm{C} 12$ and Lactobacillus acidophilus 2B4 to prevent diarrhea caused by enteropathogenic Escherichia coli (EPEC). Albino rats (Rattus norvegicus) were daily orally administered by $10^{8} \mathrm{cfu} / \mathrm{ml}$ of both probiotics without or simultaneously infected with EPEC $\left(10^{6} \mathrm{cfu} / \mathrm{ml}\right)$ for 7 days. Negative control was not infected by probiotic and EPEC while positive control was challenged with EPEC alone. After 1, 2 and 3 weeks, total of lactic acid bacteria (LAB) and E. coli of mucosa of cecum and cecum content were evaluated. It was observed that rats administered by L. plantarum $2 \mathrm{C} 12$ and L. acidophilus $2 \mathrm{~B} 4$ and challenged with EPEC had better performances when compared with the positive control for daily weight gain, feed consumption, feed efficiency rate. Diarrhea was determined by total of $E$. coli on cecum and watery fecal. Both probiotics could increase $1 \log _{10} \mathrm{cfu} / \mathrm{cm}^{2}$ of total LAB on mucosa of cecum and also $1 \log _{10} \mathrm{cfu} /$ $\mathrm{g}$ of cecum content. Both probiotics also could reduce 1-3 $\log _{10} \mathrm{cfu} / \mathrm{cm}^{2}$ population of E.coli on mucosa of cecum and $1 \log _{10} \mathrm{cfu} / \mathrm{g}$ of cecum content. L. plantarum $2 \mathrm{C} 12$ and L. acidophilus $2 \mathrm{~B} 4$ were effective as probiotics against EPEC on rats.
\end{abstract}

Key words: probiotic, Lactobacillus plantarum 2C12, Lactobacillus acidophilus 2B4, Enteropathogenic Escherichia coli

\section{PENDAHULUAN}

Probiotik didefinisikan sebagai mikroorganisme hidup yang dikonsumsi oleh manusia atau hewan dalam jumlah yang cukup, mampu hidup dan melewati kondisi lambung dan saluran pencernaan serta bermanfaat bagi sel inangnya dengan jalan meningkatkan kesehatan bagi inangnya (Savadogo et al., 2006; FAO MHO, 2002). Bakteri probiotik juga harus termasuk kelompok aman atau GRAS (Generally Recognized as Safe). Lactobacillus plantarum dan Lactobacillus acidophilus termasuk spesies bakteri yang tergolong dalam probiotik (Salminen \& Wright, 2004).

\footnotetext{
*Korespondensi:

Departemen Ilmu Produksi dan Teknologi Peternakan,

Fakultas Peternakan, Institut Pertanian Bogor

Jln. Agatis, Kampus IPB Darmaga, Bogor 16680

E-mail: irma_isnafia@yahoo.com
}

Working group yang dibentuk oleh FAOMHO menetapkan secara detil panduan dan kriteria rekomendasi serta metodologi yang digunakan untuk evaluasi probiotik, mengidentifikasi serta menentukan data yang dibutuhkan untuk mengklaim kesehatan probiotik. Kriteria pertama yang harus dipenuhi adalah bahwa isolat yang didapat harus diidentifikasi, baik secara fenotipik, maupun genotipik, mulai dari genus sampai spesies, bahkan sampai tingkatan sub spesies. Kriteria selanjutnya adalah karakterisasi fungsional, baik secara in vitro maupun studi hewan, kemudian dilanjutkan dengan pengujian keamanan secara in vitro dan in vivo serta studi fase satu di manusia (FAOMHO 2002). Bakteri dapat dinyatakan sebagai probiotik jika dapat bertahan melewati lambung dan usus halus, sehingga probiotik harus toleran terhadap suasana asam dan adanya asam empedu (Tuomola et al., 2001; Bourlioux et al., 2003; Sunny-Roberts \& Knoor, 2008).

Lactobacillus spp. dan bakteri asam laktat lainnya yang mempunyai sifat probiotik dapat ditemukan dari sumber pangan hewani. Erkilla \& Petaja (2000) melaku- 
kan isolasi bakteri asam laktat dari sosis fermentasi dan mengujinya sebagai probiotik. Tamang et al. (2008) menemukan Lactobacillus probiotik dari bambu fermentasi dan Moulay et al. (2006) meneliti bakteri asam laktat probiotik yang diisolasi dari susu. Arief et al. (2008) juga mengisolasi L. plantarum 1B1 dari daging sapi serta mengaplikasikannya sebagai kultur starter sosis fermentasi.

Probiotik mempunyai berbagai fungsi kesehatan antara lain sebagai pencegah dan mempunyai efek terapeutik melawan diare, mengurangi kejadian lactose intolerance, melindungi dari inflamasi/arthritis, mencegah hipertensi dan kanker serta meningkatkan sistem imun tubuh (Parvez et al., 2006). Probiotik juga berfungsi untuk menyempurnakan proses pencernaan manusia dengan cara melindungi saluran pencernaan dari serangan bakteri patogen (Agostoni et al., 2004). Probiotik juga dilaporkan mampu mengatasi kejadian diare yang disebabkan oleh infeksi Escherichia coli, baik E. coli enteroksigenik/ETEC (Oyetayo, 2004) maupun E. coli enterohemorargi /EHEC (Medellin-Pena \& Griffiths, 2009).

E. coli enteropatogenik (EPEC) merupakan salah satu strain dari E. coli yang menyebabkan diare jika dikonsumsi pada dosis $10^{5}-10^{10} \mathrm{cfu} / \mathrm{ml}$ (Kelleher et al., 2002). EPEC melekat pada permukaan mukosa usus dan menyebabkan terjadinya perubahan struktur sel. Selanjutnya, EPEC melakukan invasi menembus sel mukosa sehingga menyebabkan terjadinya iritasi dan diare akut. EPEC dilaporkan sering menginfeksi anak-anak. Pencegahan diare yang disebabkan oleh EPEC sangat penting dilakukan karena diare akut dapat menyebabkan kematian (Nitisinprasert et al., 2006).

Penelitian ini bertujuan untuk mengevaluasi efektivitas strain probiotik L. plantarum 2C12 dan L. acidophilus 2B4 melawan E. coli enteropatogenik penyebab diare pada tikus percobaan.

\section{MATERI DAN METODE}

\section{Persiapan Kultur Bakteri}

Bakteri asam laktat probiotik indigenus L. plantarum 2C12 dan L. acidophilus 2B4 diisolasi dari daging sapi Peranakan Ongole bagian topside dari pasar tradisional di daerah Bogor. Bakteri tersebut selanjutnya diidentifikasi secara biokimiawi berdasarkan pola fermentasi gula dan diidentifiakasi secara molekuler dengan menggunakan teknik sekuensing gen $16 \mathrm{~S}$ rRNA. Kedua kultur tersebut bersifat tahan terhadap $\mathrm{pH}$ rendah dan garam empedu. Kultur tersebut disimpan dalam bentuk liofil (freeze dried) pada suhu $-10{ }^{\circ} \mathrm{C}$. Kultur disegarkan pada media de Man Rogosa Sharp Agar (MRSA, Oxoid) dan diinkubasi pada suhu $37{ }^{\circ} \mathrm{C}$ selama 24 jam sebagai kultur induk, yang selanjutnya dibiakkan kembali dengan cara yang sama sebagai kultur kerja. Kultur kerja kemudian dihitung populasinya sampai mencapai minimal $10^{9}$ cfu/ml. Kultur kerja pada media MRSA kemudian diencerkan pada media $\mathrm{NaCl}$ fisiologis $0,85 \%$ hingga mencapai populasi $10^{8} \mathrm{cfu} / \mathrm{ml}$ yang selanjutnya siap untuk dicekokkan ke tikus percobaan.
Bakteri EPEC yang digunakan dalam penelitian ini merupakan EPEC koleksi Fakultas Kedokteran Hewan IPB yang diisolasi dari feses bayi yang terkena diare. Bakteri EPEC disegarkan dengan cara ditumbuhkan pada media eosin methylene blue agar (EMBA, Merck) selama 48 jam yang selanjutnya disimpan pada suhu $4{ }^{\circ} \mathrm{C}$ sebagai kultur induk. Selanjutnya, EPEC ditumbuhkan pada media nutrient broth (NB, Difco) selama 24 jam inkubasi pada suhu $37^{\circ} \mathrm{C}$ hingga mencapai populasi $10^{8}$ $\mathrm{cfu} / \mathrm{ml}$, sebagai kultur kerja. EPEC yang dicekokkan ke tikus percobaan disiapkan dengan cara mengencerkan kultur kerja pada media $\mathrm{NaCl}$ fisiologis 0,85\% hingga mencapai $10^{6} \mathrm{cfu} / \mathrm{ml}$.

\section{Pengelolaan Hewan Percobaan}

Hewan percobaan yang digunakan dalam penelitian ini adalah tikus putih albino norway rats (Rattus novergicus) galur sprague dawley umur 5-6 minggu berjenis kelamin jantan hasil pengembangbiakan dari Badan POM RI, dengan bobot badan awal berkisar 120-130 g. Kandang yang digunakan adalah kandang individu yang berukuran 17,5 x 23,75 x 17,5 cm, dengan sekam steril sebagai alas kandang. Suhu ruangan diatur pada 22-24 ${ }^{\circ} \mathrm{C}$ (Muchtadi 1993) dengan kelembaban udara $60 \%-70 \%$.

Ransum diberikan sebanyak 20 g per ekor per hari setiap pukul 06.00-07.00 WIB. Air minum diberikan ad libitum. Sisa ransum dikumpulkan tiap hari untuk ditimbang sehingga diketahui konsumsi ransum per ekor tikus per hari. Setiap 3 hari dilakukan penimbangan bobot badan per tikus, pencucian kandang, dan penggantian sekam.

Komposisi ransum basal disusun berdasarkan standar AOAC (2005) dengan kasein (standar protein ransum 10\%), minyak jagung sebagai sumber lemak, campuran mineral, carboxy methyl cellulose (CMC) sebagai sumber serat, dan vitamin mix yang terdiri atas vitamin A, B1, B2, B3, B6, B12, C, D3, E dan Ca-pantotenat serta pati jagung. Air minum yang digunakan adalah air minum kemasan.

\section{Perlakuan Anti-E.coli Enteropatogenik (EPEC) Secara in Vivo}

Pengujian ini dilakukan sesuai petunjuk Zoumpopoulou et al. (2008). Dua jenis kultur bakteri asam laktat probiotik indigenus L. plantarum 2C12 dan L. acidophilus 2B4 berumur 24 jam diencerkan pada media $\mathrm{NaCl}$ fisiologis $0,85 \%$ dengan populasi $10^{8} \mathrm{cfu} / \mathrm{ml}$. Selanjutnya probiotik diberikan sesuai dengan perlakuan (Tabel 1) kepada tikus percobaan sebanyak $1 \mathrm{ml}$ per ekor tikus per hari. Populasi EPEC penyebab diare yang diberikan adalah sebesar $10^{6} \mathrm{cfu} / \mathrm{ml}$ sebanyak $1 \mathrm{ml}$ per ekor tikus percobaan per hari berdasarkan pada dosis infeksi EPEC yang dapat menyebabkan diare, yaitu minimal $10^{5}$ cfu/ml (Oyetayo, 2004). Pemberian probiotik dan EPEC dilakukan dengan cara dicekok menggunakan sonde. Tikus dibagi menjadi 6 perlakuan (Tabel 1), dengan jumlah tikus setiap perlakuan sebanyak 16 ekor.

Adaptasi tikus terhadap lingkungan selama 7 hari dilakukan pada awal penelitian dengan pemberian 
Tabel 1. Perlakuan pemberian probiotik dan E. coli enteropatogenik (EPEC)

\begin{tabular}{ccc}
\hline Perlakuan & $\begin{array}{c}\text { Pemberian jenis probiotik } \\
\text { (hari ke-1 sampai ke-21) }\end{array}$ & $\begin{array}{c}\text { Jadwal pemberian } \\
\text { EPEC }\end{array}$ \\
\hline A & - & - \\
B & L. plantarum 2C12 & - \\
C & L. acidophilus 2B4 & - \\
D & L. plantarum 2C12 & Hari ke-7 sampai ke-13 \\
E & L. acidophilus 2B4 & Hari ke-7 sampai ke-14 \\
F & - & Hari ke-7 sampai ke-14 \\
\hline
\end{tabular}

Keterangan: - artinya tidak diberikan

pakan ransum basal terhadap semua tikus. Pembedahan tikus dilakukan pada hari ke-7 (minggu 1), 14 (minggu 2) dan 21 (minggu 3) dengan 4 ulangan per kelompok tikus. Peubah yang dianalisa adalah populasi BAL serta E. coli di mukosa dan isi sekum. Analisis kadar air feses dan pengamatan kondisi kesehatan tikus secara visual juga dilakukan untuk mengetahui kondisi diare yang terjadi pada tikus.

\section{Pengukuran Total BAL dan E. coli Saluran Pencernaan}

Setiap ekor tikus dibedah menggunakan metode cervicalis dislocalis lalu diambil usus bagian sekum serta isi sekum. Permukaan usus bagian dalam sekum dikerik mukosanya pada ukuran luasan $1 \times 1 \mathrm{~cm}$, dengan menggunakan spatula steril dan dimasukkan ke dalam larutan pengencer buffer phospate water (BPW) untuk selanjutnya dilakukan pengenceran yang sesuai dan pengujian total BAL dan total E. coli pada media yang sesuai. Isi sekum diambil sebanyak $5 \mathrm{~g}$ secara aseptis untuk dilakukan pengenceran dan pengujian total BAL dan E. coli. Metode yang digunakan untuk menghitung populasi BAL dan E. coli, baik pada mukosa sekum maupun pada isi sekum, adalah metode BAM (bacteriological analytical methods) (2002), dengan media pertumbuhan MRSA (Oxoid) untuk total BAL dan EMBA (Merck) untuk E. coli.

\section{Rancangan Percobaan dan Analisis Data}

Data populasi bakteri yang diperoleh ditransformasi dalam bentuk logaritma untuk selanjutnya dianalisa statistik. Data populasi bakteri dianalisa statistik dengan menggunakan rancangan acak lengkap pola faktorial, dengan metode ANOVA, dan jika perlakuan berpengaruh nyata dilakukan uji beda nyata terkecil (Steel \& Torrie, 1995). Faktor yang diberikan adalah pemberian probiotik yang berbeda pada tiap perlakuan tikus dan perbedaan waktu (minggu) yang dijadikan sebagai faktor perlakuan karena pemberian EPEC yang berbeda (Tabel 1). Data konsumsi ransum, pertambahan bobot badan (PBB), dan efisiensi ransum dianalisa dengan menggunakan rancangan acak lengkap dengan 6 perlakuan pemberian probiotik. Jika perlakuan menunjukkan pengaruh yang nyata maka dilanjutkan dengan uji Duncan. Pengamatan minggu sebagai periode pemeliharaan tidak dimasukkan sebagai perlakuan untuk analisis data seperti halnya pada data populasi bakteri karena pengambilan data bobot badan (penimbangan bobot badan) dilakukan setiap 3 hari dan penimbangan ransum dilakukan setiap hari.

\section{HASIL DAN PEMBAHASAN}

\section{Performa Tikus Percobaan}

Kejadian diare pada tikus yang dipapar EPEC muncul pada minggu kedua pemeliharaan. Tikus yang dipapar EPEC tanpa perlakuan probiotik (F) mengalami sakit diare. Nilai kadar air feses tikus F pada minggu kedua pemeliharaan adalah $63,95 \%$ yang lebih tinggi daripada tikus lainnya (A, B, C, D, dan E), yaitu berkisar $46,63 \%-52,07 \%$. Demikian juga halnya dengan kadar air feses pada minggu ketiga pemeliharaan, tikus $\mathrm{F}$ mengalami diare yang parah yang ditunjukkan dengan feses yang cair dengan kadar air 68,92\% dan kondisi tubuh yang tidak aktif bergerak. Selain itu, bagian anus tikus F mengalami peradangan dan iritasi. Lain halnya dengan tikus yang dipapar EPEC namun diberikan probiotik ( $\mathrm{D}$ dan $\mathrm{E}$ ), walaupun tergolong sakit dan bobot badannya mengalami penurunan karena konsumsi pakan yang menurun akibat infeksi EPEC, namun diare yang ditimbulkan tidak parah (ringan), dan juga bagian anus tidak mengalami peradangan ataupun iritasi. Hal ini dibuktikan dengan kadar air feses pada minggu kedua pemeliharaan, yaitu sebesar $46,63 \%$ dan $48,22 \%$, dan juga pada minggu ketiga, yaitu sebesar 53,37\% dan $57,75 \%$, yang jauh dibawah nilai kadar air feses tikus $\mathrm{F}$. Selain itu, tikus D dan E juga masih bergerak cukup aktif walaupun tidak seaktif kelompok tikus A, B, dan C.

Performa tikus percobaan ditunjukkan dengan konsumsi ransum, PBB per ekor per hari serta efisiensi ransum (Tabel 2). Konsumsi ransum pada tikus dengan perlakuan pemberian probiotik L. plantarum (B) dan $L$. acidophilus (C) nyata lebih tinggi $(\mathrm{P} \varangle 0,05)$ dibandingkan dengan tikus sakit yang dipapar EPEC. Tikus sakit yang dipapar EPEC dan juga diberikan perlakuan probiotik, yaitu tikus D dan E mempunyai tingkat konsumsi ransum yang lebih tinggi $(\mathrm{P} \varangle 0,05)$ dibandingkan dengan tikus tanpa pemberian probiotik (F) (Tabel 2). Kondisi ini menunjukkan bahwa pemberian probiotik mampu memperbaiki konsumsi ransum pada tikus yang sakit yang dipapar EPEC.

Demikian juga halnya dengan PBB tikus, pada tikus sehat $(A, B, C)$ nyata lebih tinggi dibandingkan dengan tikus sakit (D, E, F) (Gambar 1). Namun demikian, PBB pada tikus sakit diare karena dipapar EPEC dengan pemberian probiotik L. plantarum maupun L. acidophilus (tikus D, E) sangat nyata lebih tinggi $(\mathrm{P} \varangle 0,01)$ dibandingkan dengan tikus sakit diare dipapar EPEC tanpa pemberian probiotik (F). Hal ini sejalan dengan nilai konsumsi ransum pada tikus D dan E yang lebih tinggi dibandingkan dengan tikus $\mathrm{F}$.

Nilai efisiensi ransum menunjukkan bahwa tikus sehat $\mathrm{A}, \mathrm{B}, \mathrm{C}$ mempunyai nilai yang lebih tinggi $(\mathrm{P}<0,05)$ dibandingkan dengan tikus sakit diare D, E, F (Tabel 2). Hal ini disebabkan oleh rendahnya konsumsi ransum 
Tabel 2. Konsumsi ransum, pertambahan bobot badan, dan efisiensi ransum tikus percobaan yang diberi probiotik L. plantarum 2C12 dan L. acidophilus 2B4

\begin{tabular}{lcccccc}
\hline & \multicolumn{5}{c}{ Perlakuan } \\
\cline { 2 - 7 } & A & B & C & D & E & F \\
\hline $\begin{array}{l}\text { Konsumsi ransum } \\
\text { (g/ekor/hari) }\end{array}$ & $17,32 \pm 1,82^{\mathrm{a}}$ & $18,27 \pm 1,31^{\mathrm{a}}$ & $17,06 \pm 1,98^{\mathrm{a}}$ & $15,43 \pm 2,47^{\mathrm{b}}$ & $15,60 \pm 2,32^{\mathrm{b}}$ & $13,88 \pm 3,34^{\mathrm{c}}$ \\
$\begin{array}{l}\text { Pertambahan bobot } \\
\text { badan (g/ekor/hari) }\end{array}$ & $5,20 \pm 0,59^{\mathrm{A}}$ & $5,31 \pm 0,53^{\mathrm{A}}$ & $4,76 \pm 0,42^{\mathrm{A}}$ & $2,48 \pm 0,35^{\mathrm{B}}$ & $2,04 \pm 0,31^{\mathrm{B}}$ & $1,72 \pm 0,24^{\mathrm{C}}$ \\
Efisiensi ransum (\%) & $30,02 \pm 0,32^{\mathrm{a}}$ & $29,06 \pm 0,41^{\mathrm{a}}$ & $27,9 \pm 0,21^{\mathrm{b}}$ & $16,07 \pm 0,14^{\mathrm{c}}$ & $13,08 \pm 0,13^{\mathrm{d}}$ & $12,39 \pm 0,07^{\mathrm{d}}$ \\
\hline
\end{tabular}

Keterangan: superskrip huruf kecil berbeda pada baris yang sama menunjukkan berbeda nyata $(\mathrm{P}<0,05)$, superskrip huruf kapital berbeda pada baris yang sama menunjukkan berbeda sangat nyata $(\mathrm{P}<0,01) . \mathrm{A}=$ kontrol negatif (tanpa probiotik/tanpa E. coli enteropatogenik $(\mathrm{EPEC})$ ), $\mathrm{B}=$ pemberian L. plantarum, $\mathrm{C}=$ pemberian L. acidophilus, $\mathrm{D}=$ dipapar EPEC dan pemberian L. plantarum, $\mathrm{E}=$ dipapar EPEC dan pemberian $L$. acidophilus, $\mathrm{F}=$ kontrol positif (dipapar EPEC).

dan juga PBB yang menurun pada tikus sakit diare (Gambar 1). Nilai efisiensi ransum terendah dimiliki oleh tikus sakit E dan F.

L. plantarum 2C12 dan L. acidophilus 2B4 mampu memperbaiki konsumsi ransum dan PBB tikus percobaan disebabkan oleh beberapa faktor, diantaranya mampu meningkatkan absorbsi nutrien dengan memproduksi beberapa enzim pencernaan, misalnya enzim proteolitik. Selain itu, probiotik juga mampu melepaskan sejumlah asam amino bebas dan mensintesis vitamin yang sangat dibutuhkan oleh pertumbuhan inangnya (Parvez et al., 2006). Hal ini didukung oleh penelitian Oyetayo (2004) yang melaporkan bahwa probiotik L. acidophilus mampu meningkatkan bobot badan dan konsumsi ransum pada tikus yang dipapar E. coli enterotoksigenik. Gross et al. (2008) juga melaporkan bahwa pemberian probiotik $L$. plantarum 299v mampu memperbaiki konsumsi ransum dan bobot badan tikus percobaan.

\section{Total BAL Mukosa Sekum dan Isi Sekum}

Total BAL mukosa sekum. Total BAL pada mukosa sekum menggambarkan jumlah BAL yang menempel pada mukosa sekum (Tabel 3). Kemampuan menempel BAL pada usus merupakan syarat penting yang harus dipenuhi oleh probiotik (FAO $M H O$, 2002).

Berdasarkan Tabel 3, total BAL yang menempel pada mukosa sekum tikus sehat maupun tikus sakit yang diberikan probiotik (B, C, D, E) sangat nyata lebih tinggi sebanyak $1 \log _{10} \mathrm{cfu} / \mathrm{cm}^{2}(\mathrm{P}<0,01)$ daripada kelompok kontrol sehat (A) dan tikus kontrol sakit tanpa diberikan probiotik (F). Populasi BAL pada mukosa sekum tikus yang diberi probiotik (B, C, D, E) mencapai kisaran 6,31-6,52 $\log _{10} \mathrm{cfu} / \mathrm{cm}^{2}$, sedangkan pada tikus kontrol negatif (A) dan kontrol positif (F) hanya mencapai 5,59$5,72 \log _{10} \mathrm{cfu} / \mathrm{cm}^{2}$. Kondisi ini menunjukkan bahwa $L$. plantarum 2C12 dan L. acidophilus 2B4 mampu melewati berbagai hambatan di saluran pencernaan, diantaranya $\mathrm{pH}$ rendah (di lambung) dan adanya garam empedu di usus sehingga sampai di usus halus bagian sekum dan menempel pada mukosa sekum. Gross et al. (2008) juga melaporkan bahwa populasi Lactobacillus spp. di usus halus tikus percobaan dengan pemberian probiotik $L$. plantarum $299 \mathrm{v}$ lebih tinggi $\left(10^{6} \mathrm{cfu} / \mathrm{g}\right)$ daripada kontrol $\left(10^{5} \mathrm{cfu} / \mathrm{g}\right)$. Hal ini membuktikan bahwa L. plantarum mampu beradaptasi dan hidup di saluran pencernaan.

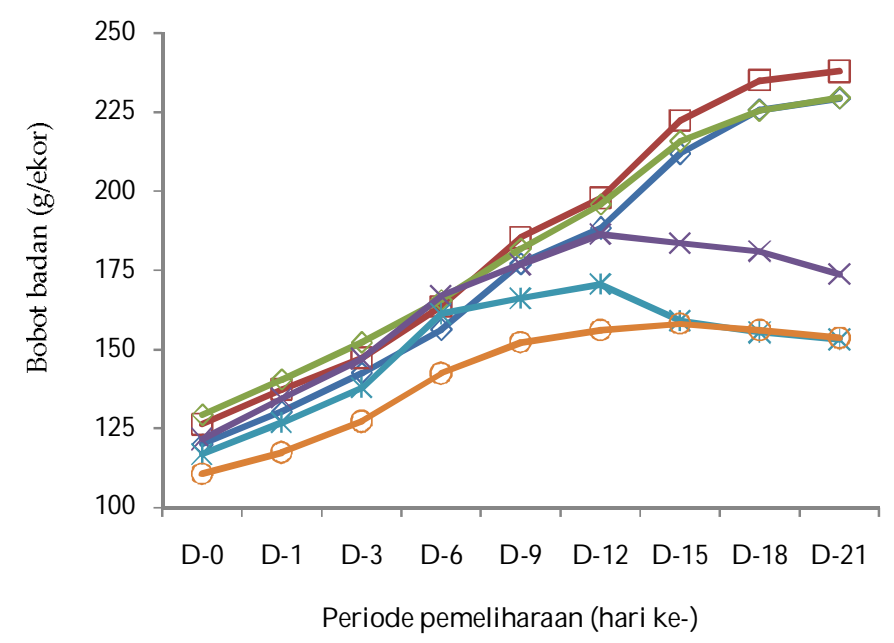

Gambar 1. Bobot badan tikus percobaan yang diberi probiotik L. plantarum 2C12 dan L. acidophilus 2B4 . (- - -) : grup kontrol negatif; (-口-) : grup L. plantarum 2C12; (-৩-) : grup L. acidophilus 2B4; (-x-) : L. plantarum 2C12 + EPEC; (--): L. acidophilus 2B4 + EPEC; (-०-) : kontrol positif. 
Tabel 3. Total BAL mukosa sekum tikus $\left(\log _{10} \mathrm{cfu} / \mathrm{cm}^{2}\right)$ yang diberi probiotik L. plantarum 2C12 dan L. acidophilus 2B4

\begin{tabular}{cccccccc}
\hline \multirow{2}{*}{ Minggu } & \multicolumn{7}{c}{ Perlakuan } \\
\cline { 2 - 7 } & A & B & C & D & E & F & Rata-rata \\
\hline 1 & $5,15 \pm 0,66$ & $6,64 \pm 0,77$ & $6,34 \pm 0,33$ & $6,60 \pm 0,19$ & $6,69 \pm 0,20$ & $5,84 \pm 0,29$ & $6,21 \pm 0,70^{\mathrm{A}}$ \\
2 & $5,56 \pm 0,50$ & $6,08 \pm 0,92$ & $5,90 \pm 0,41$ & $5,98 \pm 0,55$ & $5,88 \pm 0,62$ & $5,23 \pm 0,67$ & $5,77 \pm 0,63^{\mathrm{B}}$ \\
3 & $6,06 \pm 0,28$ & $6,66 \pm 0,47$ & $6,69 \pm 0,35$ & $6,90 \pm 0,36$ & $6,98 \pm 0,44$ & $6,10 \pm 0,38$ & $6,56 \pm 0,50^{\mathrm{A}}$ \\
Rata-rata & $5,59 \pm 0,60^{\mathrm{B}}$ & $6,46 \pm 0,73^{\mathrm{A}}$ & $6,31 \pm 0,47^{\mathrm{A}}$ & $6,49 \pm 0,53^{\mathrm{A}}$ & $6,52 \pm 0,64^{\mathrm{A}}$ & $5,72 \pm 0,57^{\mathrm{B}}$ & \\
\hline
\end{tabular}

Keterangan: superskrip huruf kapital berbeda pada baris atau kolom yang sama menunjukkan berbeda sangat nyata $(\mathrm{P} \varangle$,01). $\mathrm{A}=\mathrm{kontrol}$ negatif (tanpa probiotik/tanpa E. coli enteropatogenik (EPEC)), B= pemberian L. plantarum, $\mathrm{C}=$ pemberian L. acidophilus, $\mathrm{D}=$ dipapar EPEC dan pemberian L. plantarum, E= dipapar EPEC dan pemberian L. acidophilus, $\mathrm{F}=$ kontrol positif (dipapar EPEC).

Adlerberth et al. (2000) menyatakan bahwa Lactobacillus spp. menghasilkan senyawa adhesin sehingga mampu menempel pada mukosa usus.

Total BAL pada minggu kedua saat diberikan EPEC, lebih rendah sebesar $1 \log _{10} \mathrm{cfu} / \mathrm{cm}^{2}(\mathrm{P}<0,01)$ dibandingkan dengan minggu sebelum dan sesudah diberikan paparan EPEC. Hal ini terjadi karena pada saat terjadinya pemberian EPEC, maka jumlah EPEC pada saluran pencernaan tikus meningkat dan juga terjadi kompetisi populasi mikroflora sehingga total BAL menurun.

Total BAL isi sekum. Komposisi mikroflora isi sekum menggambarkan komposisi mikroorganisme yang terdapat pada isi makanan yang telah dicerna di usus halus yang akan menjadi feses. Sekum pada tikus merupakan tempat berlangsungnya fermentasi zat-zat makanan oleh mikroflora usus seperti halnya kolon pada usus manusia (Liong \& Shah, 2006). Total BAL isi sekum menggambarkan total BAL yang ada di feses (Tabel 4).

Total BAL pada isi sekum pada tikus sehat $(B, C)$ dan tikus sakit yang diberikan probiotik L. plantarum (D) sangat nyata lebih tinggi $(\mathrm{P}<0,01)$ dibandingkan dengan tikus sakit tanpa diberikan probiotik (F). Tikus sehat A mempunyai total BAL isi sekum yang tidak berbeda dengan tikus sakit dengan diberikan probiotik L. acidophilus (E) dan tanpa pemberian probiotik (F). Hal ini menunjukkan bahwa L. plantarum 2C12 lebih efektif meningkatkan total BAL isi sekum pada tikus yang dipapar EPEC dibandingkan dengan L. acidophilus 2B4. Perbedaan tersebut kemungkinan karena L. plantarum memproduksi senyawa adesin manosa pada dinding selnya yang dapat menempel pada mukosa usus lebih baik dibandingkan dengan spesies Lactobacillus lainnya (Gross et al., 2008), sehingga L. plantarum mampu berkembang biak dengan baik di saluran pencernaan yang menyebabkan total BAL di usus termasuk di isi sekum meningkat.

\section{Total E. coli Mukosa Sekum dan Isi Sekum}

Total E. coli mukosa sekum. EPEC dapat menginfeksi usus halus dan menyebabkan terjadinya iritasi pada mukosa usus. Terdapat perubahan populasi E. coli pada mukosa sekum pada kelompok tikus yang dipapar oleh $\operatorname{EPEC~(D,~E,~F)~(Tabel~5).~}$

Total E. coli mukosa sekum pada minggu kedua saat tikus sakit dipapar oleh EPEC pada tikus yang diberi probiotik L. plantarum $2 \mathrm{C} 12$ dan L. acidophilus 2B4, baik pada tikus sehat $(B, C)$ maupun pada tikus sakit $(\mathrm{D}, \mathrm{E})$, nyata lebih rendah $(\mathrm{P}<0,05)$ daripada tikus sakit dipapar EPEC (F) maupun tikus sehat kontrol negatif (A). Pemberian probiotik L. plantarum 2C12 dan $L$. acidophilus 2B4 (D, E) mampu menurunkan total E. coli pada mukosa sekum sebesar $1 \log _{10} \mathrm{cfu} / \mathrm{cm}^{2}$ dibandingkan dengan tikus yang dipapar EPEC tanpa diberikan probiotik (F). Secara keseluruhan baik pada minggu ke1, 2, dan 3, kondisi E coli pada mukosa sekum pada tikus yang diberikan probiotik (B, C, D, E) nyata lebih rendah daripada tikus kontrol positif (F). Hal ini menunjukkan bahwa L. plantarum 2C12 dan L. acidophilus 2B4 mampu menghambat populasi E.coli pada mukosa sekum.

Tabel 4. Total BAL isi sekum $\left(\log _{10} \mathrm{cfu} / \mathrm{g}\right)$ yang diberi probiotik L. plantarum $2 \mathrm{C} 12$ dan L. acidophilus $2 \mathrm{~B} 4$

\begin{tabular}{cccccccc}
\hline \multirow{2}{*}{ Minggu } & \multicolumn{7}{c}{ Perlakuan } \\
\cline { 2 - 6 } & \multicolumn{1}{c}{$\mathrm{A}$} & $\mathrm{B}$ & $\mathrm{C}$ & $\mathrm{D}$ & $\mathrm{E}$ & $\mathrm{F}$ & Rata-rata \\
\hline 1 & $8,73 \pm 0,21$ & $8,97 \pm 0,16$ & $8,93 \pm 0,27$ & $8,98 \pm 0,54$ & $8,64 \pm 0,63$ & $8,18 \pm 0,65$ & $8,74 \pm 0,50$ \\
2 & $8,63 \pm 0,44$ & $8,92 \pm 0,33$ & $8,95 \pm 0,51$ & $9,08 \pm 0,36$ & $8,67 \pm 0,38$ & $8,20 \pm 0,46$ & $8,74 \pm 0,48$ \\
3 & $8,49 \pm 0,09$ & $8,67 \pm 0,49$ & $8,79 \pm 0,49$ & $9,00 \pm 0,59$ & $8,79 \pm 0,37$ & $7,88 \pm 0,34$ & $8,60 \pm 0,53$ \\
Rata-rata & $8,61 \pm 0,28^{\mathrm{AB}}$ & $8,85 \pm 0,35^{\mathrm{A}}$ & $8,89 \pm 0,40^{\mathrm{A}}$ & $9,02 \pm 0,46^{\mathrm{A}}$ & $8,70 \pm 0,44^{\mathrm{AB}}$ & $8,08 \pm 0,48^{\mathrm{B}}$ & \\
\hline
\end{tabular}

Keterangan: superskrip huruf kapital berbeda pada baris yang sama menunjukkan berbeda sangat nyata $(\mathrm{P} \varangle 0,01)$. A=kontrol negatif (tanpa probiotik/tanpa E. coli enteropatogenik (EPEC)), B= pemberian L. plantarum, C= pemberian L. acidophilus, $\mathrm{D}=$ dipapar EPEC dan pemberian $L$. plantarum, E=dipapar EPEC dan pemberian L. acidophilus, F=kontrol positif (dipapar EPEC). 
Tabel 5. Total E. coli mukosa sekum tikus $\left(\log _{10} \mathrm{cfu} / \mathrm{cm} 2\right)$ yang diberi probiotik L. plantarum 2C12 dan L. acidophilus 2B4

\begin{tabular}{ccccccc}
\hline \multirow{2}{*}{ Minggu } & \multicolumn{7}{c}{ Perlakuan } \\
\cline { 2 - 7 } & A & B & C & D & E & F \\
\hline 1 & $5,12 \pm 0,51^{\text {abc }}$ & $4,66 \pm 0,33^{\text {bcd }}$ & $4,80 \pm 0,12^{\text {bcd }}$ & $4,25 \pm 0,81^{\text {bcd }}$ & $4,22 \pm 0,30^{\text {bcd }}$ & $5,42 \pm 0,25^{\text {ab }}$ \\
2 & $4,80 \pm 0,89^{\text {bcd }}$ & $3,11 \pm 0,95^{\mathrm{d}}$ & $2,95 \pm 0,93^{\text {d }}$ & $4,81 \pm 0,69^{\text {cd }}$ & $3,02 \pm 1,25^{\text {d }}$ & $5,32 \pm 1,09^{\text {ab }}$ \\
3 & $5,07 \pm 0,38^{\text {bc }}$ & $4,70 \pm 0,62^{\text {bcd }}$ & $3,35 \pm 1,00^{\text {cd }}$ & $5,62 \pm 0,85^{\mathrm{b}}$ & $5,09 \pm 0,42^{\text {bc }}$ & $6,23 \pm 0,28^{\text {a }}$ \\
\hline
\end{tabular}

Keterangan: superkrip huruf kecil yang berbeda pada baris dan kolom yang sama menunjukkan berbeda nyata $(\mathrm{P}<0,05)$. $\mathrm{A}=\mathrm{kontrol}$ negatif $($ tanpa probiotik/tanpa E. coli enteropatogenik (EPEC)), B= pemberian L. plantarum, C= pemberian L. acidophilus, $\mathrm{D}=$ dipapar EPEC dan pemberian L. plantarum, E= dipapar EPEC dan pemberian L. acidophilus, $\mathrm{F}=$ kontrol positif (dipapar EPEC).

Medellin-Pena \& Griffiths (2009) juga melaporkan bahwa probiotik mampu menghambat kolonisasi E. coli enterohemorrhagic (EHEC) pada usus tikus percobaan.

L. plantarum dan L. acidophilus menghasilkan senyawa antimikroba yang bersifat bakterisidal yang mampu menghambat pertumbuhan E. coli. L. acidophilus menghasilkan senyawa asam organik terutama asam laktat sebagai hasil metabolismenya yang bersifat antimikroba terhadap E. coli (Reque et al., 2000). Selain memproduksi asam organik terutama asam laktat, L. plantarum A-1 menghasilkan senyawa bakteriosin yang disebut dengan plantaricin ASM-1 yang mampu menghambat pertumbuhan E. coli (Hata et al., 2010). Bakteriosin mampu menghambat pertumbuhan mikroba lainnya dengan cara membentuk rongga atau pori di dinding/membran sel yang sensitif dan menurunkan potensial dan atau gradien $\mathrm{pH}$ yang menyebabkan rusaknya material seluler hingga menyebabkan sel lisis (Asaduzzaman \& Sonomoto, 2009).

Total E. coli isi sekum. Kejadian diare juga ditunjukkan dengan tingginya populasi E. coli pada isi sekum. Diare akan terjadi pada populasi yang lebih tinggi daripada $8,5 \log _{10} \mathrm{cfu} / \mathrm{g}$ feses (Medellin-Pena \& Griffiths, 2009). Kejadian diare muncul pada minggu kedua dan berlangsung sampai pada minggu ketiga pada tikus yang dipapar EPEC tanpa pemberian probiotik (F) dengan populasi E. coli mencapai $8 \log _{10} \mathrm{cfu} / \mathrm{g}$, namun dengan adanya pemberian probiotik $L$. plantarum $2 \mathrm{C} 12$ dan $L$. acidophilus 2B4 (D, E) maka populasi E. coli isi sekum dapat ditekan pada populasi $7 \log _{10} \mathrm{cfu} / \mathrm{g}$, sehingga tidak terjadi diare walaupun dipapar EPEC (Tabel 6).
Pemberian probiotik L. plantarum 2C12 dan L. acidophilus 2B4 mampu menurunkan total E. coli pada isi sekum hingga minggu ketiga (Tabel 6). Saat tikus dipapar EPEC (tikus D, E, F) pada minggu kedua, total E. coli isi sekum pada tikus yang diberikan probiotik L. plantarum 2C12 dan L. acidophilus 2B4 (D dan E) nyata lebih rendah sebesar $1 \log _{10} \mathrm{cfu} / \mathrm{g}(\mathrm{P} \varangle 0,05)$ dibandingkan dengan tikus kontrol positif (F). Demikian juga halnya dengan tikus sehat yang diberikan probiotik $L$. plantarum $2 \mathrm{C} 12$ dan L. acidophilus 2B4 (B, C) juga mempunyai total E. coli isi sekum lebih rendah $1 \log _{10} \mathrm{cfu} / \mathrm{g}(\mathrm{P}<0,05)$ dibandingkan dengan tikus kontrol negatif (A). L. plantarum 2 C12 dan L. acidophilus 2B4 mampu menurunkan jumlah E. coli pada isi sekum sebesar $1 \log _{10}$ cfu/g dan mampu mencegah terjadinya diare setelah dipapar EPEC.

Total E. coli yang dihitung pada penelitian ini merupakan total E. coli fekal, yang tidak secara khusus menghitung populasi EPEC. Walaupun pada tikus A (kontrol negatif) total $E$. coli baik pada minggu 1, 2, dan 3 cukup tinggi $(8,28-8,89$ log $\mathrm{cfu} / \mathrm{g})$ dan tidak berbeda dengan tikus $\mathrm{F}$ (kontrol positif), namun tikus A tidak mengalami diare sedangkan kelompok tikus $\mathrm{F}$ mengalami diare parah. Hal ini disebabkan oleh strain E. coli yang berada di saluran pencernaan tikus A dan F yang berbeda. E. coli merupakan bakteri yang sebagian strainnya bersifat patogen namun sebagian yang lain bersifat nonpatogen. E. coli nonpatogen merupakan mikroflora normal saluran pencernaan terutama di sekum dan kolon, dan tidak menyebabkan kejadian diare. Kemungkinan besar total E. coli yang terhitung pada tikus $\mathrm{F}$ adalah gabungan antara E. coli nonpatogenik dan EPEC yang sengaja diinfeksikan pada penelitian ini, sedangkan total E. coli yang dihitung pada tikus A merupakan E. coli nonpa-

Tabel 6. Total E. coli isi sekum tikus ( $\left.\log _{10} \mathrm{cfu} / \mathrm{g}\right)$ yang diberi probiotik L. plantarum $2 \mathrm{C} 12$ dan L. acidophilus 2B4

\begin{tabular}{ccccccc}
\hline \multirow{2}{*}{ Minggu } & \multicolumn{5}{c}{ Perlakuan } \\
\cline { 2 - 7 } & A & B & C & D & E & F \\
\hline 1 & $8,34 \pm 0,65^{\text {ab }}$ & $8,07 \pm 0,12^{\text {abc }}$ & $8,08 \pm 0,21^{\text {abc }}$ & $7,72 \pm 0,91^{\text {bcd }}$ & $7,54 \pm 0,10^{\text {bcd }}$ & $8,25 \pm 0,67^{\text {ab }}$ \\
2 & $8,28 \pm 1,00^{\text {ab }}$ & $7,01 \pm 0,77^{\text {cd }}$ & $6,30 \pm 0,91^{\text {d }}$ & $7,86 \pm 0,56^{\text {bcd }}$ & $6,72 \pm 0,99^{\text {cd }}$ & $8,60 \pm 0,13^{\text {a }}$ \\
3 & $8,89 \pm 0,35^{\text {a }}$ & $7,99 \pm 0,03^{\text {bcd }}$ & $7,26 \pm 0,91^{\text {bcd }}$ & $7,90 \pm 0,57^{\text {bcd }}$ & $7,97 \pm 0,07^{\text {bcd }}$ & $8,96 \pm 0,51^{\text {a }}$ \\
\hline
\end{tabular}

Keterangan: superskrip huruf kapital berbeda pada baris atau kolom yang sama menunjukkan berbeda sangat nyata (P $\varangle$,01). A= kontrol negatif (tanpa probiotik/tanpa E. coli enteropatogenik (EPEC)), B= pemberian L. plantarum, $\mathrm{C}=$ pemberian L. acidophilus, $\mathrm{D}=$ dipapar EPEC dan pemberian L. plantarum, E=dipapar EPEC dan pemberian L. acidophilus, F= kontrol positif (dipapar EPEC). 
togen. Hal inilah yang menyebabkan walaupun total $E$. coli yang dihitung pada isi sekum tikus A tidak berbeda dengan tikus $\mathrm{F}$, namun dampak yang diakibatkannya sangat berbeda yaitu tikus A tidak mengalami diare namun tikus $\mathrm{F}$ mengalami diare parah.

\section{KESIMPULAN}

Pemberian probiotik L. plantarum 2C12 dan L. acidophilus 2B4 mampu meningkatkan konsumsi ransum, pertambahan bobot badan, dan efisiensi ransum pada tikus yang dipapar EPEC dibandingkan dengan tikus tanpa pemberian probiotik. Kedua galur probiotik tersebut juga terbukti efektif mencegah diare yang disebabkan oleh EPEC dengan jalan meningkatkan total bakteri asam laktat di mukosa dan isi sekum, serta menurunkan total E.coli pada mukosa dan isi sekum.

\section{UCAPAN TERIMA KASIH}

Penulis mengucapkan terima kasih kepada DP2M Ditjen DIKTI, Kementerian Pendidikan Nasional yang telah memberikan dana untuk penelitian ini melalui Penelitian Hibah Bersaing tahun 2009.

\section{DAFTAR PUSTAKA}

AOAC (Association of Official Analytical Chemist). 2005. Official Methods of Analysis. Washington, DC.

Adlerberth, I., M. Cerquetti, I. Poilane, A. Wold, \& A. Collignon. 2000. Mechanisms of colonization and colonization resistance of the digestive tract. Part 1: bacteria host interactions. Microb. Ecol. Health Dis. 2: 223-239.

Agostoni, C., I. Axelsson, C. Braegger, O. Goulet, B. Koletzko, K. F. Michaelsen, J. Rigo, R. Shamir, H. Szajewska, D. Turck, \& L. T. Weaver. 2004. Probiotic bacteria in dietetic products for infants : a commentary by the ESPHGHAN Committee on Nutrition. J. Pediatr Gastroenterol. Nutr. 28: 365-374.

Arief, I. I., R. R. A. Maheswari, T. Suryati, Komariah, \& S. Rahayu. 2008. Kualitas mikrobiologi sosis fermentasi daging sapi dan domba yang menggunakan kultur kering Lactobacillus plantarum 1B1 dengan umur yang berbeda. Med. Pet. 31: 36-43.

Asaduzzaman, S. M. \& K. Sonomoto. 2009. Lantibiotics: Diverse activities and unique modes of action. J. Biosci. \& Bioeng. 107: 475-487.

BAM (Bacteriological Analytical Methods) Online. 2001. http://www.cfsan.fda.gov/ ebam.html. [7 Agustus 2009]

Bourlioux, P., B. Koletzko, F. Guarner, \& V. Braesco. 2003. The intestine and its microflora are partners for the protection of the host: report on the Danone symposium 'The Intelligent Intestine', held in Paris, June 14, 2002. Am. J. Clin. Nutr. 78: 675-683.

Erkilla S. \& E. Petaja. 2000. Screening of commercial meat starter cultures at low $\mathrm{pH}$ and in the presence of bile salts for potential probiotic use. Meat Sci. 55: 297-300.

FAO/ WHO. 2002. Guidelines for the evaluation of probiotics in food. Report of Joint FAO $/ \mathrm{WHO}$ Working Group on drafting Guidelines for the evaluation of probiotics in food. London Ontario, Canada.

Gross, G. J. Wildner, A. Schonewille, J. L. W. Rademaker, R vander Meer, \& J. Snel. 2008. Probiotic Lactobacillus plantarum $299 \mathrm{v}$ doesnot unfavorable phytohematoglutinin induced changes in the rat intestinal microbiota. Appl. Environ. Microbiol 74: 5224-5249.
Hata, T., R. Tanaka, \& S. Ohmomo. 2010. Isolation and characterization of plantaricin ASM 1: a new bacteriocin produced by Lactobacillus plantarum A-1. International J. Food Microbiol. 137:94-99.

Kelleher, S. I. Casas, N. Carbaja, \& B. Lonnedal. 2002. Supplementation of infant formula with the probiotic Lactobacillus reuteri and zinc : impact on enteric infection nutrition in infant rhesus monkeys. J. Pediatr Gastroenterol. Nutr. 35 : 162-168.

Liong, M. T. \& N. P. Shah. 2006. Effects of a Lactobacillus casei synbiotic on serum lipoprotein, intestinal microflora and organic acids in rats. J. Dairy Sci. 89:1390-1399.

Medellin-Pena, M. J. \& M. W. Griffiths. 2009. Effects of molecules secreted by Lactobacillus acidophilus strain La-5 on Escherichia coli O157:H7 Colonization. Appl. Environ. Microbiol 75: 1165-1172.

Moulay, M., H. Aggad, Z. Benmechernene, B. Guessas, \& M. Kihal. 2006. Cultivable lactic acid bacteria isolated from Algerian raw goat's milk and their proteolytic activity. World J. Dairy \& Food Sci. 1: 12-18.

Muchtadi, D. 1993. Teknik Evaluasi Nilai Gizi Protein. Program Pasca Sarjana. Institut Pertanian Bogor, Bogor.

Nitisinprasert, S., N. Pungsungworn, P. Wanchaitanawong, G. Loiseau, \& D. Montet. 2006. In vitro adhesion assay of lactic acid bacteria, Escherichia coli and Salmonella sp. by microbiological and PCR methods. Songklanakarin J. Sci. Technol. 28 (suppl.1): 99-106.

Oyetayo, V. O. 2004. Performance of rats orogastrically dosed with faecal strains of Lactobacillus acidophilus and challenged with Escherichia coli. Afr. J. Biotechnol. 3: 409-411.

Parvez, S., K. A. Malik, S. Ah. Kong, \& H. Y. Kim. 2006. Probiotics and their fermented food products are beneficial for health. Review article. J. Appl. Microbiol. 100: 1171-1185.

Reque, E. F., A. Pandey, S. G.Franco, \& C. R. Soccol. 2000. Isolation, identification and physiological study of Lactobacillus acidophilus LPB for use as probiotic in chickens. Braz. J. Microbiol. 31: 303-307.

Salminen, S. \& A. V. Wright. 2004. Lactic Acid Bacteria. Microbiology and Functional Aspects. $2^{\text {nd }}$ Edition, Revised and Expanded. Marcell Dekker, Inc., New York.

Savadogo, A., C. A. T. Outtara, I. H. N. Bassole, \& A. S. Traore. 2006. Bacteriocins and lactic acid bacteria - a minireview. Afr J Biotechnol. 5: 678-683.

Steel, R. G. D. \& J. H. Torrie. 1995. Principles and Procedur of Statistic. A Biometrical Approach. $2^{\text {nd }}$ Ed. Mc.Graw Hill International Book Co., London.

Sunny-Roberts, E. O. \& D. Knoor. 2008. Evaluation of the response of Lactobacillus rhamnosus VTT E-97800 to sucroseinduced osmotic stress. Food Microbiol. 25: 183-189.

Tamang, B., U. Schilinger, C. A. M. P. Franz, M. Gores, \& W. H. Holzapfel. 2008. Phenotytpic and genotypic identification of lactic acid bacteria isolated from ethnic bamboo tender shoots of North East India. Int. J. Food Microbiol. 121: 35-40.

Tuomola, E., R. Crittenden, M. Playne, E. Isolauri, \& S. Salminen. 2001. Quality assurance criteria for probiotic bacteria. Am. J. Clin. Nutr. 73 (suppl): 393S-398S.

Zoumpopoulou, G., B. Foligne., K. Christodoulou, C. Grangette, B. Pot, \& E. Tsakalidou. 2008. Lactobacillus fermentum ACA-DC 179 displays probiotic potential in vitro and protects againts trinitrobenzene sulfonic acid (TNBS)-induced colitis and Salmonella infection in murine models. Int. J. Food Microbiol. 121: 18-19. 